\title{
The impact of COVID-19 in the healthcare workforce in Peru
}

\author{
Jesús Neyra-León ${ }^{1}\left[\right.$. J Jhonel Huancahuari-Nuñez ${ }^{2}$. \\ Juan Carlos Díaz-Monge ${ }^{1,3}$. Joseph A. Pinto ${ }^{1}$
}

Accepted: 23 September 2020 / Published online: 7 October 2020

(c) Springer Nature Limited 2020

\section{Dear Editors,}

The coronavirus disease 2019 (COVID-19) outbreak has subdued all health systems, wreaking havoc throughout the world. As of 6 September 2020, the World Health Organization (WHO) has reported more than 27 million cases of COVID-19 and nearly 900 thousand deaths for this disease. The American continent reached more than 14 million cases and the most affected countries are the United States, Brazil, and Peru [1]. In Peru, as 6 September 2020, official reports from the ministry of health include 683,702 positive cases by either immunologic or molecular tests, and mortality is estimated to be approximately $4.34 \%$ [2].

On 15 March 2020, the Peruvian government initiated a countrywide quarantine, thus becoming the first country in the American continent to enter in an emergency state [3]. The government closed its borders, initially for 15 days. At that time, Peru had 71 COVID-19 confirmed cases; cases and deaths then increased exponentially, and Peru extended the quarantine on 31 July 2020, and then focused quarantine in some provinces until 30 September 2020. Unfortunately, given the national socioeconomic context, Peru could not effectively handle the quarantine. Approximately $70 \%$ of the workforce in Peru is made up of informal workers who had no income during the extended quarantine. After a few weeks, the absence of these resources resulted in breaking of the quarantine and triggered a collapse of sanitary measures that we now live with.

This pandemic has showed the real dimensions of the crisis in our health system. Nearly 50\% of our healthcare workforce serve in Lima, the capital city of Peru. This creates shortages and inequalities in geographic distribution of health personnel in

Jesús Neyra-León

jesus.24.47.1996@gmail.com

1 Escuela Profesional de Medicina Humana, Universidad Privada San Juan Bautista, Carretera

Panamericana Sur Km 300, Ica 11004, Peru

2 Escuela Profesional de Medicina Humana, Universidad Nacional de San Cristóbal de Huamanga, Portal Independencia $N^{\circ}$ 57, Ayacucho 05000, Peru

3 Departamento de Medicina, Hospital Regional de Ica, Avenida prolongación Ayabaca s/n (Camino a Huacachina), 11004 Ica, Peru 
Table 1 Peruvian population and physicians infected and killed by COVID-19 in Peru ([2, 8] Source: Ministry of health of Peru and Peruvian Medical College as of 6 September 2020)

\begin{tabular}{|c|c|c|c|c|c|c|}
\hline \multirow[t]{2}{*}{ Geographical regions } & \multicolumn{3}{|c|}{ Total population } & \multicolumn{3}{|c|}{ Physicians } \\
\hline & Infected & Deaths & Case fatality (\%) & Infected & Deaths & Case fatality (\%) \\
\hline Coast & 518,343 & 24,935 & 4.81 & 2275 & 116 & 5.10 \\
\hline Highlands & 62,907 & 2,217 & 3.52 & 750 & 27 & 3.60 \\
\hline Jungle & 102,452 & 2,535 & 2.47 & 651 & 27 & 4.15 \\
\hline
\end{tabular}

the country. There are additional structural and organizational deficiencies, such as lack of specialized laboratories, scarce intensive care units (ICU), and the scarcity of personal protection equipment (PPEs) [4, 5]. Undoubtedly, under these adverse conditions, healthcare personnel have been the perfect target for this virus [6].

In Peru, 58,404 physicians are practicing across the country, 21.9\% of whom are $>60$ years old, making them highly susceptible to COVID-19 [7]. According to a report from the Peruvian Medical College (PMC) by 6 September 2020, 3,676 physicians had contracted COVID-19, 81 of whom were hospitalized in ICU with mechanical ventilation, and 170 had died. The Peruvian coast is the geographical region with the highest mortality and percent case fatality among physicians (Table 1) [8]. The Peruvian Obstetrician College report that as of 6 September 2020, a total of 2035 obstetricians had contracted COVID-19 and 21 had died [9]. Unfortunately, there is no information about other categories of healthcare professionals.

Complicating this tragic situation, is a lack of efficient coordination between representatives of the central government, the Ministry of Health, and regional governments. Our health system was not prepared to handle the demand of health services because of these deficits and the result was the collapse of healthcare system, despite constant technical advice of the Peruvian Medical College (PMC) about how to manage the pandemic [10]. The system was ill prepared to handle the vastly increased needs for care. The PMC has had to use its own economic resources to mitigate the difficult situations of COVID-19 infected physicians in remote areaseven paying private air transportation to Lima (the capital city) for critically ill patients in search of better opportunities treatment [11].

Despite the new measures and extension of the state of emergency until the end of September 2020 declared by the Peruvian government to diminish the contagion rate, the future remains uncertain in our country [12]. It is urgent to improve the working conditions for the healthcare workforce, including the provision of more PPE, prioritization of attention to infected personnel, to improve the telehealth attention and allocate more financial resources in health. Only with these actions will Peru have more opportunities to manage adequately our COVID-19 patients.

Author contributions All authors participated in the conception, design, writing, critical review and approval of this paper.

Funding None. 


\section{Compliance with ethical standards}

Conflict of interest Authors declare they have not potential conflict of interest with this work.

\section{References}

1. WHO Coronavirus Disease (COVID-19) Dashboard I WHO Coronavirus Disease (COVID-19) Dashboard [Internet]. https://covid19.who.int/. Accessed 6 Sep 2020.

2. Covid 19 en el Perú - Ministerio del Salud [Internet]. https://covid19.minsa.gob.pe/sala_situaciona 1.asp. Accessed 5 June 2020.

3. Decreto Supremo N 044-2020-PCM I Gobierno del Perú [Internet]. https://www.gob.pe/institucion/ pcm/normas-legales/460472-044-2020-pcm. Accessed 4 June 2020.

4. Inga-Berrospi F, Arosquipa RC. Avances en el desarrollo de los recursos humanos en salud en el Perú y su importancia en la calidad de atención. Rev Peru Med Exp Salud Publica. 2019;36(2):312.

5. Maguiña Vargas C. Reflexiones sobre el COVID-19, el Colegio Médico del Perú y la Salud Pública. ACTA MEDICA Peru [Internet]. 2020 Mar 31;37(1). https://amp.cmp.org.pe/index.php/AMP/artic le/view/929. Accessed 4 June 2020.

6. Ing EB, Xu A, Salimi A, Torun N. Physician deaths from corona virus (COVID-19) disease. Occup Med (Chic Ill).

7. Buerhaus PI, Auerbach DI, Staiger DO. Older clinicians and the surge in novel coronavirus disease 2019 (COVID-19). JAMA. 2020;323(18):1777-8.

8. Médicos con Covid-19 Positivo (Autoreporte) - Colegio Médico del Perú - Consejo Nacional [Internet]. https://www.cmp.org.pe/medicos-con-covid-19-positivo-autoreporte/. Accessed 4 June 2020.

9. REPORTE DE OBSTETRAS CON COVID-19 - Colegio de Obstetras del Perú [Internet]. https:// colegiodeobstetras.pe/reporte_de_obstetras_con_covid_19/. Accessed 19 July 2020.

10. WEB-Comunicados-N39-11-de-mayo-2020.png $(1000 \times 1333)$ - Colegio Médico del Perú - Consejo Nacional [Internet]. https:/www.cmp.org.pe/wp-content/uploads/2020/05/WEB-Comunicado s-N39-11-de-mayo-2020.png. Accessed 19 July 2020.

11. CMP TRASLADA A LA CIUDAD DE LIMA A MÉDICOS CONTAGIADOS CON COVID -19 - Colegio Médico del Perú - Consejo Nacional [Internet]. https://www.cmp.org.pe/cmp-traslada-ala-ciudad-de-lima-a-medicos-contagiados-con-covid-19/. Accessed 4 June 2020.

12. Decreto Supremo N ${ }^{\circ}$ 094-2020-PCM I Gobierno del Perú [Internet]. https://www.gob.pe/institucion/ pcm/normas-legales/584231-094-2020-pcm. Accessed 4 June 2020.

Publisher's Note Springer Nature remains neutral with regard to jurisdictional claims in published maps and institutional affiliations.

Jesús Neyra-León MBSS, is medical intern at the Hospital Regional de Ica, Ica, Ica, Perú.

Jhonel Huancahuari-Nuñez MBSS, is medical student at the Universidad Nacional de San Cristóbal de Huamanga, San Juan Bautista, Huamanga, Ayacucho, Perú.

Juan Carlos Díaz-Monge MD, is physician at the Hospital Regional de Ica, Ica, Ica, Perú.

Joseph A. Pinto BS, is Professor at the Universidad Privada San Juan Bautista, Ica, Ica, Ica, Perú. 